\title{
An In Vivo Radiographic Evaluation of the Accuracy of Apex and iPex Electronic Apex Locators
}

\author{
Laura PALUDO ${ }^{1}$ \\ Sophia Lopes de SOUZA ${ }^{1}$ \\ Marcus Vinícius Reis $\mathrm{SO}^{2}$ \\ Ricardo Abreu da ROSA ${ }^{3}$ \\ Fabiana Vieira VIER-PELISSER ${ }^{4}$ \\ Marco Antônio Húngaro DUARTE ${ }^{5}$ \\ ${ }^{1}$ UNICSUL - Cruzeiro do Sul University, Caxias do Sul, RS, Brazil \\ ${ }^{2}$ Department of Conservative Dentistry, Dental School, \\ UFRGS - Federal University of Rio Grande do Sul, Porto Alegre, RS, Brazil \\ ${ }^{3} U F R G S$ - Federal University of Rio Grande do Sul, Porto Alegre, RS, Brazil \\ ${ }^{4}$ Clinical Department, Dental School, PUCRS - Pontifical Catholic University \\ of Rio Grande do Sul, Porto Alegre, RS, Brazil \\ ${ }^{5}$ Department of Endodontics, Bauru Dental School, USP - University of São Paulo, Bauru, SP, Brazil
}

\begin{abstract}
The aim of this study was to evaluate in vivo the clinical applicability of two electronic apex locators (EALs) - Apex (Septodont) and iPex (NSK) - in different groups of human teeth by using radiography. The working lengths (WLs) of 100 root canals were determined electronically. The EAL to be used first was chosen randomly and a K-file was inserted into the root canal until the EAL display indicated the location of the apical constriction $(0 \mathrm{~mm})$. The $\mathrm{K}$-file was fixed to the tooth and a periapical radiograph was taken using a radiographic film holder. The K-file was removed and the WL was measured. The same procedure was repeated using the other EAL. Radiographs were examined with the aid of a light-box with lens of $\times 4$ magnification by two blinded experienced endodontists. The distance between the file tip and the root apex was recorded as follows: (A) +1 to $0 \mathrm{~mm}$, (B) -0.1 to $0.5 \mathrm{~mm},(\mathrm{C})-0.6$ to $1 \mathrm{~mm}$, (D) -1.1 to $1.5 \mathrm{~mm}$, and (E) $-1.6 \mathrm{~mm}$ or greater. For statistical purposes, these scores were divided into 2 subgroups according to the radiographic apex: acceptable (B, C, and D) and non-acceptable (A and E). Statistically significant differences were not found between the results of Apex and iPex in terms of acceptable and non-acceptable measurements $(p>0.05)$ or in terms of the distance recorded from file tip and the radiographic apex $(\mathrm{p}>0.05)$. Apex and iPex EALs provided reliable measurements for WL determination for endodontic therapy.
\end{abstract}

Key Words: electronic apex locator, radiographic apex, working length.

\section{INTRODUCTION}

Endodontic therapy comprises cleaning, disinfecting, shaping and filling of the root canal system. Root canal preparation and filling should not extend beyond the tooth root, and nor should any uninstrumented areas remain inside the canals (1). Over-instrumentation may cause periradicular inflammation, postoperative pain, and inhibition of the healing process. On the other hand, under-instrumentation causes the apical areas to remain unresponsive to the effects of irrigation agents or intracanal dressings (2).
Working length (WL) determination and maintenance is therefore of major importance. The WL is "the distance from a coronal reference point to the point at which canal preparation and filling should terminate" (3). Anatomically, the apical constriction (AC) indicates the apical limit for the termination of endodontic treatments (4), and as it often coincides with the narrowest diameter of the root canal. It also helps in WL determination (3). Locating the AC and the cementodentinal junction (CDJ) in a clinical setting, however, is critical. The location of the CDJ varies in relation to the apical foramen (5). It is widely accepted

Correspondence: Dr. Ricardo Abreu da Rosa, Universidade Federal do Rio Grande do Sul, Rua Gomes Carneiro, 408, 97050-470 Santa Maria, RS, Brasil. Tel: +55-55-9927-5625. email: rabreudarosa@yahoo.com.br 
as being $0.50-0.75 \mathrm{~mm}$ coronal to the apical foramen (6). Additionally, the clinical determination of the $\mathrm{AC}$ and the radiographic determination of the WL have certain limitations such as distortion, shortening and elongation, interpretation variability, and lack of threedimensional representation. Even when a paralleling technique is used, elongation of images has been found to be approximately $5 \%$ (7).

Custer (8) was the first to propose an electronic method to locate the apical foramen. Suzuki (9) observed the electrical resistance of oral tissues, and this observation contributed to the development of the first electronic apex locator (EAL) by Sunada (10). The device was resistance-based and measured the resistance between two electrodes to determine the location of an instrument in the root canal. In the 1980's, the second-generation EAL was developed. It was an impedance-based device and had the inherent ability to prevent the passage of alternating electric current. The third-generation EAL was frequency-dependent and measured impedance values at 2 frequencies $(8 \mathrm{KHz}$ and $0.4 \mathrm{KHz}$ ) simultaneously in order to calculate a quotient, which expresses the position of the file tip in the canal (11). The recently developed fourth-generation EAL measures capacitance and resistance simultaneously to determine the location of the file tip in the canal (12).

Several studies have investigated the use of the EALs, their accuracy in endodontic treatment (12-16) and retreatment (17), the influence of prior preflaring (18), and their coefficient of repeatability (13).

Apex (Septodont, Barueri, SP, Brazil) is a thirdgeneration apex locator. It is a frequency-based device, does not require calibration, and can function in a wet environment, for instance, in the presence of purulent secretion and blood. The iPex (NSK, Tokyo, Japan) is claimed to be a fourth-generation apex locator. It automatically selects the best possible combination of frequency in line with the canal condition by simultaneously measuring capacitance and resistance to determine the location of the file tip in the canal $(12,19)$.

Therefore, Apex and iPex have different mechanisms and could possibly differ in terms of reliability. The purpose of this study was to evaluate in vivo the accuracy of these two EALs in determining the WL compared with the radiographic method.

\section{MATERIAL AND METHODS}

This study was conducted at the Cruzeiro do Sul
Postgraduate School (Caxias do Sul, RS, Brazil). One hundred root canals with completely formed apices indicated for endodontic therapy were included in the study (Fig. 1). Patients having teeth with internal and external resorptions, root canal obliteration, and root perforation were excluded from the study, so were pregnant women and patients with pacemakers.

This research protocol was approved by the Ethics Committee of the University of Passo Fundo, Brazil, and informed written consent in full accordance with ethical principles was obtained from each patient before the treatment was initiated.

Diagnostic radiographs were taken using a 66 $\mathrm{kV}$ dental x-ray generator: Gnatus Time 66 (Gnatus, Ribeirão Preto, SP, Brazil), periapical films (Kodak Ekta Speed, São Paulo, SP, Brazil) exposed for $0.32 \mathrm{~s}$, and a radiographic film holder (Indusbelo, Londrina, PR, Brazil) was used (15). Radiographs were processed by the time/temperature method, and the processing liquids were changed after the 10th use. Local anesthesia was administered (2\% mepivacaine with norepinephrine 1:100,000, Mepinor; DFL, São Paulo, SP, Brazil), and the teeth were isolated with rubber dam. Caries and existing metal restorations were removed, and cavity preparations were carried out using high-speed round diamond burs under water coolant.

After the root canal orifices were located, root canal exploration was performed using a \#10 stainless steel K-file (Dentsply Tulsa Dental, Tulsa, OK, USA) This was followed by irrigation with $1 \%$ and $2.5 \%$ $\mathrm{NaOCl}$ (Calêndula Pharmacy, Porto Alegre, RS, Brazil) in cases of vital and nonvital pulp, respectively. Thereafter, coronal portions of the root canals were flared using LA Axxess (SybronEndo, Glendora, CA, USA) or Gates Glidden Drills (Dentsply Ind. e Com. Ltda., Petrópolis, RJ, Brazil) according the canal diameter.

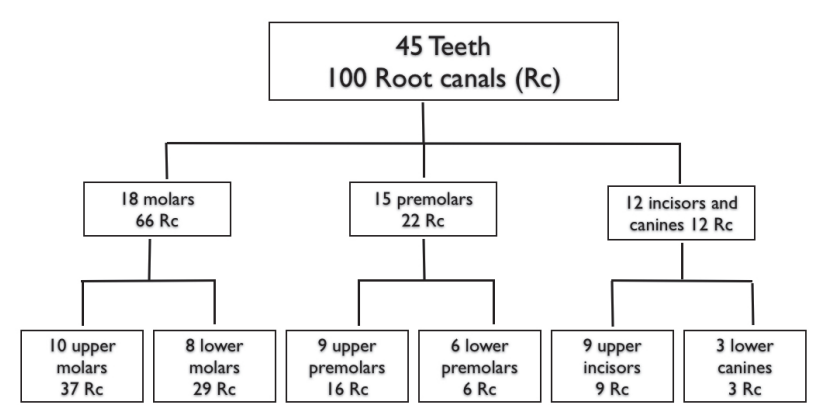

Figure 1. Schematic view of the number of teeth and root canals evaluated by each EAL. 
The final rinse was aspirated but no attempt was made to dry the canals.

Both EALs (iPex and Apex) were used in each canal according to the manufacturer's instructions for WL determination. The EAL to be used first was selected on a random basis. The minor foramen was located using the EAL (this limit was established by observing the reference $0 \mathrm{~mm}$ on the display of each locator). Then, the silicone stop on the file was positioned at the reference point established previously, and the file was removed from the canal. The WL was measured and the values were noted. This was immediately followed by radiographic examination with the use of a radiographic film holder (Indusbelo). The same procedure was carried out using the other EAL in order to compare the measurements obtained with both devices.

Radiographs were wrapped in black cardboard and examined using a light-box with lens of $\times 4$ magnification (Bio Art, São Paulo, SP, Brazil). All measurements were recorded by 2 experienced endodontists blinded to the group assignment of the patients.

Radiographically, the distance between file tip and root apex was recorded as: (A) +1 to $0 \mathrm{~mm}$, (B) -0.1 to $0.5 \mathrm{~mm}$, (C) -0.6 to $1 \mathrm{~mm}$, (D) -1.1 to $1.5 \mathrm{~mm}$, and (E) $-1.6 \mathrm{~mm}$ or higher. A minus symbol (-) indicated a file short of the root apex; a plus symbol $(+)$ indicated a file that extended beyond the apex.

For statistical purposes, these scores were divided into two subgroups according to the radiographic apex: acceptable (B, C and D) and non-acceptable (A and E). The results were analyzed statistically using the Kendall test to evaluate the compatibility between evaluators. Fisher's exact test was used to compare the EALs for acceptable and non-accetable measurements, and a Student's t-test for dependent samples was used to compare the different distances of the apex between the two locators. The evaluations were conducted at a significance level of $5 \%$.

Table 1. EAL's acceptable (0.1-1.5 short of radiographic apex RA) and non-acceptable (1-0 mm beyond the radiographic apex and $\geq 1.5 \mathrm{~mm}$ short of radiographic apex) measurements.

\begin{tabular}{lccc}
\hline EAL & Acceptable & Non-acceptable & Total \\
\hline Apex & 84 & 16 & 100 \\
Ipex & 82 & 18 & 100 \\
Total & 166 & 34 & 200 \\
\hline
\end{tabular}

Chi-square test, $\alpha=0.05, \mathrm{p}=0.7900$.

\section{RESULTS}

The Kendall test resulted at a significance level of $5 \%$ and showed satisfactory interexaminer agreements with values commencing from 0.70 .

In terms of the radiographic apex, the acceptable and non-acceptable measurements are presented in Table 1. The acceptable measurements were found to be predominant in the cases of both EALs $(84 \%$ on Apex and $82 \%$ on iPex), with no statistically significant difference $(\mathrm{p}>0.05)$.

Table 2 presents the mean distance between the file tip and the radiographic apex obtained from the EALs. Apex and iPex did not show any statistically significant differences $(\mathrm{p}>0.05)$.

\section{DISCUSSION}

In recent times, EALs have gained popularity. Even in the event of errors caused by metallic restorations, salivary contamination, and dehydration, the accuracy of the EAL is superior to that of a radiograph. Moreover, they are not affected by distortion, magnification, interpretation variability, or lack of three-dimensional representations as in the case of radiographs (7).

Several groups of teeth were selected for the present study, unlike in previous studies that used only single-rooted or multi-rooted teeth $(13,20,21)$. Coronal flaring was carried out before recording the measurements, with the aim of removing dentin interferences, which led not to only easier file insertion but also to an increase in EAL precision in determining the WL $(18,22)$.

EAL-based studies should attempt to employ different methodologies, namely, the determination of the apical limits and the limit of location of the apical constriction (13). The present study aimed at determining the position of the apical constriction indicated by both types of EALs. To determine the apical limits, a reference

Table 2. Means and standard deviation (s.d.) of the distance from file tip to the radiographic apex.

\begin{tabular}{lc}
\hline EAL & Mean and s.d. \\
\hline Apex & $0.85(0.56)$ \\
Ipex & $0.74(0.50)$ \\
\hline
\end{tabular}

Student's t-test, $\alpha=0.05, \mathrm{p}=0.3081 . \mathrm{n}=100$ measurements for both EALs. 
point should be established, which will aid obtaining accurate measurements. Some researchers consider the minor diameter or apical constriction (15), whereas others consider the major diameter or apical foramen (14) for this purpose. Variations in the apical third permit a maximum apical limit of $1 \mathrm{~mm}$ coronal to the major foramen for endodontic therapy $(5,23)$.

The distance between the file tip and the radiographic apex displayed by the EAL ranged from 0.1 $\mathrm{mm}$ to $1.5 \mathrm{~mm}$ in most cases (84\% for Apex and $82 \%$ for iPex; $p=0.79$ ). This variation may be considered acceptable, due to the wide range in the location of the apical constriction (4-6). The values obtained by iPex are in accordance with a recent in vitro study that showed $76.3 \%$ precision in determining the WL when the display indicated a distance of $1 \mathrm{~mm}$ from the apex, and $97.4 \%$ when the display indicated $0 \mathrm{~mm}$ (12). These data seem to clearly indicate that the accuracy of iPex increase as the file tip approaches the apex. The present study showed $82 \%$ of acceptable radiographic measurements when the display indicated the apical constriction. This result is supported by the findings of De Vasconcelos et al. (12). The Apex had a value of $84 \%$ of acceptable radiographic measures, which is slightly higher than the values obtained by Camargo et al. (18) when preflaring was not carried out $(77.5 \%)$ and lower than those obtained when preflaring was carried out (87.5\%).

With regard to the non-acceptable values, (A) +1 to $0 \mathrm{~mm}$, and (E) $-1.6 \mathrm{~mm}$ or higher, the Apex and the iPex displayed a greater number of overestimated readings $(10 \%$ and $16 \%$, respectively, in $\mathrm{A})$ than of underestimated ones $(6 \%$ and $2 \%$, respectively, in E) Both these situations are unfavorable for endodontic procedures. Overestimated readings can lead to over-instrumentation, possible debris extrusion, and microbiological contamination of the periradicular tissues (24), resulting in overfilling and consequent healing impairment. In contrast, underestimated readings can lead to the persistence of bacterial content and necrotic tissue in the root canal, adversely affecting the outcome of endodontic therapy (2).

The mean distance between the file tip and the radiographic apex was $0.85 \mathrm{~mm}$ on Apex and $0.74 \mathrm{~mm}$ on iPex, showing no statistically significant difference $(p=0.30)$. It is important to emphasize that these values are related to the radiographic apex and not to the apical foramen. The foramen opening may be located 1 or 2 $\mathrm{mm}(6), 3 \mathrm{~mm}$ (15), and even $3.4 \mathrm{~mm}$ away from the radiographic apex (5). Moreover, even in straight roots, the foramen opening is rarely located at the root apex in $70 \%$ to $80 \%$ of the cases (4).

Considering some of the limitations of this study, Apex and iPex EALs provided a high percentage of acceptable values for WL determination for endodontic therapy.

\section{RESUMO}

O objetivo deste estudo foi avaliar, in vivo, a aplicabilidade clínica de dois localizadores apicais eletrônicos (LAEs) - Apex (Septodont) e iPex (NSK) - em diferentes grupos de dentes humanos usando análise radiográfica. Os comprimentos de trabalho de 100 canais radiculares foram determinados eletronicamente. O LAE a ser usado primeiro foi escolhido randomicamente e uma lima tipo $\mathrm{K}$ foi inserida no canal radicular até que o visor do aparelho indicasse a localização da constrição apical $(0 \mathrm{~mm})$. A lima foi fixada na coroa do dente e uma radiografia periapical foi realizada utilizando posicionador radiográfico. Em seguida, a lima foi removida e o comprimento de trabalho foi mensurado. O mesmo procedimento foi realizado para o segundo LAE. As radiografias foram analizadas em negatoscópio com lupa de $\times 4$ por dois endodontistas experientes, cegos em relação aos grupos. A distância entre a ponta da lima e o ápice radiográfico foi classificada como: (A) + 1 a $0 \mathrm{~mm}$; (B) - 0,1 a 0,5 mm; (C) - 0,6 a 1 mm; (D) - 1,1 a 1,5 mm; e (E) - 1,6 $\mathrm{mm}$ ou mais. Para fins estatísticos, esta classificação foi dividida em dois sub-grupos: aceitável (B, C, D) e não aceitável (A e E). Não foi observada diferença estatisticamente significante entre Apex e iPex em relação às medições consideradas aceitáveis e não aceitáveis $(\mathrm{p}>0,05)$ e nem à distância da ponta da lima e o ápice radiográfico $(\mathrm{p}>0,05)$. Os localizadores apicais Apex e iPex apresentaram medidas odontométricas confiáveis para o tratamento endodôntico.

\section{REFERENCES}

1. Barbizam JVB, Fariniuk LF, Marchesan MA, Pécora JD, SousaNeto MD. Effectiveness of manual and rotary instrumentation techniques for cleaning flattened root canals. J Endod 2002; 28:365-366.

2. Kielbassa AM, Muller U, Munz I, Monting JS. Clinical evaluation of the measuring accuracy of Root ZX in primary teeth. Oral Surg Oral Med Oral Pathol Oral Radiol Endod 2003; 95:94-100.

3. American Association of Endodontists (AAE). Glossary of Endodontic Terms, 7th ed. Chicago, IL: American Association of Endodontists; 2003.

4. Kuttler Y. Microscopic investigation of root apexes. J Am Dent Assoc 1955;50:544-552.

5. Dummer PM, McGinn JH, Rees DG. The position and topography of the apical canal constriction and apical foramen. Int End $\mathrm{J}$ 1984;17:192-198.

6. Ricucci D, Langeland K. Apical limit of root canal instrumentation and obturation, part 2. A histological study. Int Endod J 1998;31:394-409.

7. Vande Voorde HE, Bjorndahl AM. Estimating endodontic "working length" with paralleling radiographs. Oral Surg Oral Med Oral Pathol Oral Radiol Endod 1969;27:106-110.

8. Custer LE. Exact methods of location the apical foramen. J Nat 
Dent Res 1918;5:815-819.

9. Suzuki K. Experimental study on iontophoresis. J Jap Stomato 1942;16:411-417.

10. Sunada I. New method for measuring the length of the root canals. J Dent Res 1962;41:375-387.

11. Kobayashi C, Suda H. New electronic canal measuring device based on the ratio method. J Endod 1994;20:111-114.

12. De Vasconcelos BC, do Vale TM, de Menezes AS, PinheiroJunior EC, Vivacqua-Gomes N, Bernardes RA, et al.. An ex vivo comparison of root canal length determination by three electronic apex locators at positions short of the apical foramen. Oral Surg Oral Med Oral Pathol Oral Radiol Endod 2010;110:e57-e61.

13. D'Assunção FLC, Albuquerque DS, Salazar-Silva JR, dos Santos VC, Sousa JCN. Ex vivo evaluation of the accuracy and coefficient of repeatability of three electronic apex locators using a simple mounting model: a preliminary report. Int Endod J 2010;43:269274.

14. Guise GM, Goodell GG, Imamura GM. In vitro comparison of three electronic apex locators. J Endod 2010;36:279-281.

15. Elayouti A, Dima E, Ohmer J, Sperl K, von Ohle C, Lost C. Consistency of apex locator function: a clinical study. J Endod 2009;35:179-181.

16. Vieyra JP, Acosta J, Mondaca JM. Comparison of working length determination with radiographs and two electronic apex locators. Int Endod J 2010;43:16-20.

17. Aggarwal V, Singla M, Kabi D. An in vitro evaluation of performance of two electronic root canal length measurement devices during retreatment of different obturating materials. J Endod 2010;36:1526-1530.
18. Camargo EJ, Zapata RO, Medeiros PL, Bramante CM, Bernardineli N, Garcia RB, et al.. Influence of preflaring on the accuracy of length determination with four electronic apex locators. J Endod 2009;35:1300-1302.

19. Stober EK, Duran-Sindreu F, Mercade M, Vera J, Bueno R, Roig $\mathrm{M}$. An evaluation of root ZX and iPex apex locators: an in vivo study. J Endod;37:608-610.

20. Goldberg F, Frajlich S, Kuttler S, Manzur E, Briseno-Marroquin B. The evaluation of four electronic apex locators in teeth with simulated horizontal oblique root fractures. J Endod 2008;34:1497-1499.

21. Jakobson SJ, Westphalen VP, da Silva Neto UX, Fariniuk LF, Picoli F, Carneiro E. The accuracy in the control of the apical extent of rotary canal instrumentation using Root ZX II and ProTaper instruments: an in vivo study. J Endod 2008;34:13421345.

22. Ibarrola JL, Chapman BL, Howard JH, Knowles KI, Ludlow MO. Effect of preflaring on Root ZX apex locators. J Endod 1999;25:625-626.

23. Shabahang $\mathrm{S}$, Goon WW, Gluskin $\mathrm{AH}$. An in vivo evaluation of Root ZX electronic apex locator. J Endod 1996;22:616-618.

24. Higa RA, Adorno CG, Ebrahim AK, Suda H. Distance from file tip to the major apical foramen in relation to the numeric meter reading on the display of three different electronic apex locators. Int Endod J 2009;42:1065-1070.

Received June 17, 2011 Accepted December 13, 2011 